\title{
A NOTE ON MUSLIM JUDGES AND THE PROFESSIONAL CERTIFICATE*
}

\author{
Mohd Daud BAKAR \\ International Islamic University Malaysia
}

As any student of Islamic law would be aware that the Shari' $a$ demands the enforcement of justice, the establishment of the Islamic judicial institution would be essential without which justice and fairplay can never be upheld. Instead, tyranny and arbitrariness will be rampant. For this very reason, the Islamic judiciary evolved during the time of the Prophet himself: the appointment of both 'Alī and $\mathrm{Mu}$ 'ādh as qāọis in Yemen' and 'Uttāb b. 'Usayd in Mecca. ${ }^{2}$ Abū Bakr, the first Caliph, continued the practice; he

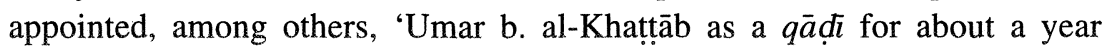
(though none appeared before him). ${ }^{3}$ Generally speaking, during the reign of the Rightly Guided Caliphate, the judicial institution took a form similar to that in the period of the Prophet. There was no demarcation of judicial powers from that of other powers. The institution was headed by the Caliph who was assisted by several appointed deputies. ${ }^{4}$

As for the Umayyad period, sources mention that the Caliphs were not involved in appointing judges neither in the capital nor in the leading towns of the great territorial divisions. ${ }^{5}$ The administration of justice was left to provincial governors and their legal secretaries. ${ }^{6}$ However, the most significant contribution of the Umayyads was the establishment of the

\footnotetext{
* Paper presented at II Joseph Schacht Conference on Theory and Practice in Islamic Law, organised by the Consejo Superior de Investigaciones Científicas (CSIC), Granada, Spain, 16-20th. December, 1997.

1 Wakī', Abū Bakr Muhammad b. Khalaf, Akhbār al-Quḍāt, Beirut, n.d., vol. 1, 84-88, 98.

2 Arnūs, Muhammad, Ta'rìkh al-Qaḍā' fi l-Islām, Cairo, n.d., 11.

${ }^{3}$ Ibid., vol. 1, 104.

${ }^{4}$ Madhkūr, Muhammad Salām, al-Qaḍā' fĩ l-Islām, Cairo, n. d., 22-23; 'Shabārū, 'Īsã Muhammad, al-Qadā' wa al-Qudāt fí l-Islām (al-'Asr al- 'Abbāsī), Beirut, 1983, 19. However, Ibn Khaldūn reported that it was 'Umar al-Khațāb who started appointing judges independent from the local governors. See Ibn Khaldūn, The Muqaddimah (An Introduction to History), translated from the Arabic by Franz Rosenthal, London, 1967, vol. 1, 453.

5 Wakī', Akhbār al-Quḍāt, vol. 1, 141 and vol. 3, 235. The report speaks about the appointment of Ibn Lahī'a that is, «he was the first judge in Egypt ever appointed by the Caliph and was paid 30 dinars monthly as salary. This is because, previously, the local governors used to appoint the judges» (ibid.).

${ }^{6}$ Schacht, J., An Introduction to Islamic Law, Oxford (reprinted 1991), 52.
} 
Mazālim court. ${ }^{7}$ This establishment enabled the public to seek redress against officials including judges.

It was the Abbasid Caliphate which introduced a significant change in the appointment and dismissal of judges. Under the Abbasids, judges were appointed in the same manner as governors ( $w \bar{a} \bar{l} \bar{l})$, that is by the same appointing authority i. e. the Caliph in Baghdād. Under this arrangement, theoretically speaking, judges were perceived to be on equal footing with local governors. ${ }^{8}$ Equally interesting is that under the Abbasids, the judiciary was put under the control of the central goverment by creating the post of Chief-Judge ( $Q \bar{a} d \bar{l} \hat{l}$ al$Q u d \bar{a} t$ ), the highest judicial post. ${ }^{9}$ The post signified that all subordinate judges were to work under the Chief-Judge. The credit for this significant move is due to Caliph Hārūn al-Rashīd because prior to his time, qā dịs or judges, irrespective of whether they were appointed to the capital or to the various provinces, were of equal status with no hierarchy among themselves. ${ }^{10}$

As far as the writer is concerned this move by the Caliph was not an unexpected one. The Abbasid goverment was very much disposed to the centralisation of political power, administration as well as law and justice. Abū Ja 'far al-Manșūr, for example, in contrast to the practice of the Umayyads, started to appoint not only judges but also governors and administrators to centralise all such appointments. Since the appointment of both judges and governors in the past was left to the local authority, the act of Abū Ja 'far was a new initiative to bring all political and administrative tasks under the proper central control of the goverment in Baghdād. ${ }^{11}$ As the provincial administration was kept under governors appointed by the Caliph in the capital city, likewise, the judicial administration was entrusted to the provincial $q \bar{a}(\bar{c} i$ appointed by the central goverment.

Centralisation led to standardisation. Abū Ja' far al-Manșūr tried to persuade Imām Mālik to agree to make the Muwațta' the sole and ultimate reference for all judges and muftis throughout the Abbasid goverment. However, Imām Mālik declined for a purely academic reason. ${ }^{12} \mathrm{Had}$ Imām Mālik agreed to this

\footnotetext{
${ }^{7}$ Al-Māwardī, Abū 1-Hasan 'Alī b. Muhammad, al-Ahkām al-Sultāniyya wa al-Wilāyāt alDiniyya, Cairo, 1983, 73-74.

${ }^{8}$ Shabārū, al-Qadă', 19.

9 Al-Anbārī, 'Abd al-Razzāq 'Alī, Manșab Qãọi al-Qựāt fí al-Dawla al- 'Abbāsiyya, Beirut, 1987, 91-92.

${ }^{10}$ Encyclopaedia of Islam, [New Edition], vol. 4, 374.

"1 Al-Khațīb al-Baghdādī, Abū Bakr Aḥmad b. 'Alī, Ta'rìkh Baghdād, Madina, n. d., vol. 14, 103; Ibn Khallikān, Shams al-Dīn, Wafayāt al-A 'yān wa Anbā' Abnā' al-Zamān, ed. Muhammad Muhyī al-Dīn 'Abd al-Ḥamīd, Cairo, 1948, vol. 2, 243; Wakī', Akhbār al-Quḍāt, vol. 1, 141.

i2 Al-Qāọī 'Iyāạ, Mūsā, Tartīb al-Madārik wa Taqrìb al-Masālik li-Ma'rifat A lām Madhhab Mālik, vol, 1, 192-193.
} 
proposal, the Abbasids would have been the first Islamic goverment to make Islamic figh uniform and «codified».

Soon after this, the next head of state of the Abbasid goverment namely, Hārūn al-Rashīd continued his predecessor's aspiration. He persuaded another leading jurist namely, Abū Yũsuf (d. 182/798), to compile the principles of the law of taxation or revenue which resulted in the writing of Kitāb al-Kharāj. Not only that, Hārūn al-Rashīd moved further to consolidate the position of ChiefJudge ( $Q \bar{a} d \underline{c} \bar{l} a l-Q u d \bar{a} t)$ which was an adaptation of the Persian institution of mobedan-mobed. ${ }^{13}$ The first $q \bar{a}$ ă to be appointed to this highest post in the history of Islamic judiciary was Abū Yūsuf ${ }^{14}$, the author of Kitāb al-Kharāj. ${ }^{15}$ Under the purview of this institution, at least in theory, the Chief $Q \bar{a} d \underline{c} \grave{i}$ was supposed to be appointed by the Caliph and the former in turn, by delegation from the Caliph, appointed $q \bar{a}$ dis subordinate to him to various parts of the city and to outlying districts. In other words, the qāọi al-quḍat is, above all, a judge. However, to him was delegated the judicial administration: the nomination, control and dismissal of judges. ${ }^{16}$

The inclination and measures of the Abbasid goverment to centralise all matters pertaining to political and administrative tasks inclusive of judicial administration have been seen as the evidence of their long-standing political statements and claims that the goverment which overthrew the Umayyads was more legitimate and pious. The stand of the Abbasids was very clear and they had made it clear on most political occasions after they overthrew the Umayyads. One of the many examples is the speech delivered by Abu Ja 'far alManșur when he visited Mecca. He addressed the people of Mecca considering himself as the ruler appointed by Allah to administer this world. Also, he disclosed his pious intentions to rule the people of Mecca with the guidance and help from Allah. ${ }^{17}$

$\mathrm{Abu} \mathrm{Ja}^{\text {' }} \mathrm{far}$ is also reported to have explicitly mentioned that judgeship is one of the four important pillars of his goverment. ${ }^{18}$ The Abbasids manifested

13 Encyclopaedia of Islam, [New Edition], vol. 4, 374.

14 Al-Tanūkhī, Abū 'Alī al-Muhạssin b. 'Alī, Nishwār al Muḥạ̣̄ara wa Akhbār al-Mudhākara, ed. 'Abbūd al-Shaljī, Beirut, 1971-1973, vol. 1, 253.

15 Ibn al-Nadīm, Muhammad b. Ishạā, al-Fihrist, Beirut, n. d., 286.

16 Al-Tanūkhī, Nishwār al Muhāạara, vol. 3, 136; vol. 4, 180 and vol. 5, 19.

17 Ibn Qutayba, Abū Muhammad 'Abd Allāh b. Muslim, 'Uyūn al-Akhbār, Cairo, 1925, vol. 2, 251: Ayyuhā al-nās innamā anā sultān Allāh fì arḍihi, asūsukum bi tawfiqihi wa tasdìdihi wa ta'yidihi wa tabșirihi (see ibid.)

${ }^{18} \mathrm{Ibn}$ al-Athīr, 'Izz al-Dīn Abū al-Ḥasan 'Alī b. Muhammad, al-Kāmil fi al-Ta'rìkh, Beirut, 1985 , vol. 5, 46. In addition to the appointment of a judge, he also mentioned the other remaining three posts which are of significant importance for the goverment, namely head of police, head of 
this desire and claim by calling all persons in their domains, including the rulers, to abide by Shari`ah principles. ${ }^{19}$ This included judicial administration. For this very reason, the Abbasid caliphs paid serious attention to the appointment of judges because, as expressed by al-Manșūr: «I am responsible to my people to appoint their judges who are firm and uphold justice so that injustice may be avoided and the status of scholars is upgraded». ${ }^{20}$ On this, Schacht noted: «Under the Abbasids, when the main features of the Shari`ah had already been definitely established, when Islamic law had come to be recognised, in theory at least, as the only legitimate norm of behaviour for Muslims, and when the kādīs, bound to apply this law, were appointed by the central goverment under the direct authority of the Caliph, the caliph himself had to be incorporated into the system». ${ }^{21}$ The special attention shown by the Abbasids to judgeship is substantiated by the remuneration granted to the judge and his assistants. ${ }^{22}$

\section{ABBASID JUDGES IN EGYPT (132-254/750-868): AN OVERVIEW}

The main purpose of this part of the discussion is to shed some light on each and every judge appointed in Egypt so as to apprehend the general features and trends of judgeship during this period. To begin with, we may note that Egypt, unlike the capital Baghdad, had experienced different political and legal developments than Baghdad and, perhaps other provinces and localities. Egypt (also known as Miṣr) was conquered by 'Amr b. al-'Āṣ in 18-21/639-641. Following the conquest, it came under the governors appointed by the Rightly Guided Caliphs (21-38/641-658). Later, Egypt was ruled by governors affiliated to the Umayyad government (38-132/658-750) before it was taken over by the

\footnotetext{
revenue and reporter to the goverment (șähib al-barīd) (ibid.). The last post is closely related to the judgeship as the reporter is supposed to report the performance of the judges directly to the Caliph at the central goverment (see al-Balawī, Salamah Muhammad al-Hirfí, al-Qad̦ā' fí al-Dawla alIslāmiyya Ta' rīkhuhu wa Nuzumuhu, Riyad, 1994, 158 ff.). This contributed quite obviously to some dismissals of the judges in Egypt as will be shown later (see al-Kindī, Abū 'Umar Muhammad b. Yūsuf, Ta'rīkh Wulāt Mișr wa-yalīhi Kitāb Tasmiyyat Quḍătihā, Beirut, 1987, 289-290).

${ }^{19}$ Kamali, Muhammad Hāshim, «Shari‘a», The Encyclopaedia of Religion, MacMillan Publishing Company, New York and London, 1997, vol. 7, 433. 243.

${ }^{20}$ Al-Khațỉ al-Bagdādī, Ta' rìkh Baghdād, vol, 14, 103; Ibn Khallikān, Wafayāt al-A 'yān, 2,

${ }^{21}$ Schacht, An Introduction to Islamic Law, 52.

${ }^{22}$ In year $155 \mathrm{~A}$. H. a judge in Egypt used to receive 30 dinars for the salary for one month. Later, Caliph al-Ma'mūn increased the salary to 160 dinars per month. See al-Kindī, Wulāt Mișr, 369,421 .
} 
Abbasids (132-254/750-868). After this period, Egypt was subject to the rule of the Tulunids for a number of years (254-292/868-905) before the Abbasids were able to recover Egypt from the Tulunids. The second victory over Egypt lasted for only 31 years before the control of Abbasids of Egypt (and elsewhere) started to decline and fell to many dynasties and the Mamluks. ${ }^{23}$

As this paper concerns only the first part of Abbasid rule and governance of Egypt, it will exclude the second part of Abbasid rule which was restored after the defeat of the Tulunids in 292/905. The first part of the Abbasid rule extended over 122 years and it appointed 22 judges throughout this period. ${ }^{24}$ The judges, generally speaking, were of diverse legal education background. Also, their terms of appointment varied. A few of them were reappointed after dismissal. ${ }^{25}$ Some of them were acting as judges before they were officially appointed to the bench. ${ }^{26}$ Also, interestingly, the reasons that led to the dismissals (except in the case of death) were of different categories and kinds which are worth reflection as far as qualifications for judgeship are concerned.

Before we discuss issues of both appointment and dismissal of judges, it is worth presenting the general state of judgeship and judicial administration in that period as an essential introduction to a more analytical type of research later on. Generally speaking, all the judges were appointed by the Caliph in Baghdad who was also vested with the authority to dismiss and remove the judges from the post. This is simply because the power of appointment was vested in the Caliph or in persons empowered by the Caliph. Self-appointment of a $q \bar{a} d \underline{\imath} i$ was out of the question. ${ }^{27}$ Some of the appointments were either based on nomination by scholars in Baghdad or scholars of the respective localities, or local governors, or personal desire of the Caliph. Therefore, there are cases where the judges were appointed by the local governors instead of the Caliph as in the case of 'Abd Allāh b. Țāhir who appointed 'Īsā b. al-Munkadir in 212/828. ${ }^{28}$ Interestingly, in this particular appointment, six potential candidates were proposed to 'Abd Allāh $b$. Țāhir but the governor was more inclined to appoint ' '̄sā simply because the latter was known to be simple and undemanding. ${ }^{29}$ Although most of the

23 Encyclopaedia of Islam [Old Edition], vol. 2, 5.

24 Excluding judges who were appointed for more than one time.

25 For example, Ghawth b. Sulaymān was appointed to the post of judgeship for three times while al-Mufaḍdal b. Faḍāla was appointed for two times. See al-Kindī, Wulāt Miṣr, 269, 272, 282, 285,290

${ }^{26}$ See the cases of Ghawth b. Sulaymān and Yazīd b. 'Abd Allāh b. Bilāl (al-Kindī, Wulāt Miṣrr, 269, 271-272).

27 'Ațiyya, Nizāam al-Qaḍā' fì al-Islām, Cairo, 1969, 24.

28 Al-Kindī, Wulāt Misr, 326.

29 Ibid., 328. 
judges were appointed by the central goverment, only al-Ma'mūn visited Egypt in 217/832 when he was away from Baghdad for a military mission. As no judge was appointed to the post after the dismissal of Judge 'Īsā b. al-Munkadir in 214/830, al-Ma'mūn had to temporarily appoint Yahyā b. Aktham after alMa'mūn failed to persuade 'Alī b. Ma'bad b. Shaddād to take the office. ${ }^{30}$ There was another case in which a judge was initially appointed by a local governor and later endorsed by the Caliph. A good example is the appointment of Judge al-Mufaḍdal b. Faḍāla for the second time by the local governor Dāwūd b. Yazīd b. Hâtim where the appointment was later confirmed by a letter from Hārūn alRashid. $^{31}$

Although the Abbasids had introduced the institution of $q \bar{a}$ ḍ̆ al-quḍat, the appointment of judges, particularly in provinces outside Baghdad as in the case of Egypt, was carried out mostly by the local governors as in the cases of the appointment of Khayr b. Nu'aym (133-135/751-753) ${ }^{32}$, Ghawth b. Sulaymān (135-140/753-758) ${ }^{33}$, Abu Khuzayma (144-154/762-771), etc. Equally true is that most of the appointment letters came directly from the Caliph in Baghdad which reinforced the centralization adopted by the Abbasids. The first person to be appointed as a judge by the central goverment direct was 'Abd Alläh $b$. Lahī'a al-Ḥadramī (155-164/772-781) $)^{34}$ followed by al-Mufaḍdal b. Faḍāla (168-169/785-786) ${ }^{35}$, 'Abd al-Rahmān b. 'Abd Allāh al-'Umarī (185-194/801$810)^{36}$, etc. In this respect, the qāộl al-qud̄at, in the Abbasid period, was perceived to have played a role only in presenting or nominating candidates. ${ }^{37}$

Having said this, we may question whether this was actually the practice. However, upon a thorough study, it appears that there was hardly any instance during that period, for the Chief-Judge even nominating candidates for the post let alone exercise the power of appointing judges. In most cases, the Caliph or the

30 Ibid., 333.

31 Ibid., 290.

32 Ibid., 268. Waki' named the Judge as Jubayr instead of Khayr b. Nu'aym (Akhbār al-Qud̄at, vol. 3,232 )

33 Ibid., 269.

34 Ibid., 278; Ibn Ḥajar al-'Asqalānī, Muhammad b. 'Alī, Raf' al-Iṣr 'an Qựāt Miṣr, ed. Hāmid 'Abd al-Majīd, Muhammad al-Mahdī Abū Sinnah and Muhammad Ismā'îl al-Ṣāwī, n. p., n. d., vol. 2, 288.

35 Al-Kindī, Wulāt Mišr, 285. He was appointed by Mūsā b. Mus'ab, then the governor of Egypt, as the latter was instructed by the Caliph al-Mahdi to issue an appointment letter on the Caliph's behalf (ibid)

36 Ibid., 296.

37 Encyclopaedia of Islam [New Edition], vol. 4, 374. It was only after the Fatimid caliphate and onwards that the qāộl al-quḍat was able to exercise their powers personally, as part of the general delegation that they had received (ibid.). 
local governors, as the case may be, consulted the local scholar instead of qātị alqudat for nominations of candidates and appointment of judges. At this stage, a preliminary conclusion may be made that the notion of centralised administration of justice by introducing the institution of qā

Also, from an overall perspective, it seems that the period of office of judges was not uniform. While some of the judges enjoyed relatively longer period at their posts, others had to serve for very short periods before they were removed or dismissed for one reason or another. For comparison, I cite the cases of Hārūn b. 'Abd Allāh al-Mālikī (217-226/832-841) and Muhammad b. Abī al-Layth alKhawārizmī (226-237/841-852) who both had served for nearly eleven years each $^{38}$ and the case of Ibrāhīm b. Ishāa al-Qārī (204-205/820-821) who served only for six months. ${ }^{39}$ The longest period of service of a judge belongs to Judge Bakkār b. Qutayba. He held office for 24 years, 6 months and 16 days. $^{40}$ It is equally interesting to note that some of the judges were appointed to the post more than once as in the case of Ghawth b. Sulaymān. He held the office three times and died while he was in service. ${ }^{41}$ As for the reasons leading to termination of office, with the exception of death ${ }^{42}$, they vary and will be discussed later in detail.

From a jurisdictional point of view, the judges were given limited jurisdictions i. e. restricted to civil cases such as the administration of mosques, waqfs, family law and bayt al-māl. Although the judges were competent in both civil and criminal matters, the religious nature of their office led to limiting their jurisdictions to civil cases. ${ }^{43}$ The literature on the biography as well as on the institution of judicial administration indicates

${ }^{38}$ See al-Kindī, Wulāt Miṣr, 334-338, 339-350.

39 Ibid., 321.

${ }^{40}$ Ibid., 362.

41 Ibid., 269-271, 272-274 and 282-284.

42 Once a $q \bar{a} \bar{c} \hat{\imath}$ died, his post is terminated and all the cases in his trials are transferred to another $q \bar{a}$ đ̣̆i. See al-Khașsāf, 'Umar b. 'Abd al-'Azīz, Sharḥ Ādāb al-Qāđịi, Baghdād, 1978, vol. 3,152 .

${ }^{43}$ This phenomenon even from the very early Islamic legal history has affected the development of Islamic law in Muslim societies. Therefore, it is not surprising to conclude that, «Historically, the areas of Shari'a law that were most developed in the classical figh corresponded to the areas where qadis in the Shari'a court were best able to retain jurisdiction over disputes, while legal issues in other areas tended to be dealt with by secular tribunals with more flexible procedures and greater enforcement powers, such as the police tribunals. The Shari'a rules of intestate succession and family law are the two most developed portions of the Shari'a, and recourse to Shari'a courts [perhaps the writer meant by Shari'a court the qā $\bar{d} i$ 's court] was very common for resolution of disputes on these subjects. The Shari'a courts also had jurisdiction over pious endowment (awqā $f$ ) which were very important legal institutions in traditional Islamic societies, allowing for the consolidation and protection of private property and often providing the financial basis for schools, hospitals, mosques and other public institutions». See Kamali, «Shari'a», 441. 
clearly that Muslim judges in the past were more involved in civil cases rather than in criminal cases. As for the literature on the biography of the judges such as al-Kindī's Kitäb Wulāt Mișr, most of the cases cited are of civil cases whereas criminal cases are hardly to be found.$^{44}$ Surprisingly, the literature on the institution of judicial administration (e. g. al-Aḥkām al-Sultāniyya) reinforces the above finding. Al-Māwardī, for example, in his al-Aḥkām al-

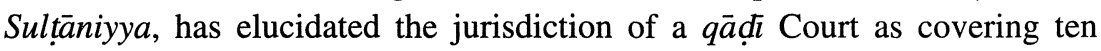
areas all of which are civil cases in character. He wrote that the jurisdiction of a $q \bar{a} \bar{c} \bar{\imath}$ lies in resolving disputes; preventing tyranny and safeguarding the rights of those whose rights have been infringed; administration of property of the person who has no capacity to administer them namely, orphans, infants, lunatics and the like; administering waqf property; executing a will in accordance with the terms stipulated in it; acting as a wali hăkim (legal guardian on behalf of the Caliph or head of state) to a woman who has no wali provided that the couple who intend to marry are compatible ( $k u f$ '); removing any obstacles on the public road or on an open area and similar action; scrutinising and deciding on the competence and integrity of potential witnesses and ensuring that the judgement or sentence is passed impartially regardless the fact that the party is strong or weak. ${ }^{45}$ The limits on the jurisdiction of a $q \bar{a} d \underline{i}$ Court are due to the fact that criminal cases and the like fall outside the jurisdiction of the qa ădi's Court; they were administered in special courts such as mazālim court, hisba, shurța and qaḍa ' al- 'askar. ${ }^{46}$

\section{NECESSARY QUALIFICATION TO QADISHIP/JUDGESHIP}

It is now necessary to embark on the main theme of the paper which is the qualifications necessary for a person to be appointed to be a judge of the qa $\bar{a} \underline{\imath}$ Court with special reference to the Abbasid judges of Egypt. The question of qualification is always related to another significant matter, that is, the training scheme that a potential and prospective judge should undergo to qualify for the post. Not many works are presently available which shed light on the actual training schemes adopted by the early Muslim societies in producing capable jurists and practitioners to serve both academic institutions and the courts.

\footnotetext{
${ }^{44}$ In al-Kindī's Wulät Missr, there are a few criminal cases reported such as the cases on qadhf and blasphemy against the Prophet (Wulāt Mișr, 269 and 288).

45 Al-Māwardī, al-Ahkām al-Sultāniyya, 78-79.

${ }^{46}$ Encyclopaedia of Islam [New Edition], vol. 4, 374.
} 
Perhaps, the works of George Makdisi would be of some help on the early history of Islamic education.

When the Abbasids took over the Caliphate from the Umayyads, the madhhab or guild of law in Islam was not yet established. Potential jurists, $q \bar{a} d_{i} i \mathrm{~s}$ and muftis, as the case may be, were trained academically in certain localities by leading Companions and Succesors who happened to reside here. It was only in the declining years of the Umayyads, that one sees the emergence of schools of law in certain localities where the founders lived. Obviously, during this period, there was no attempt to introduce a kind of professional certificate or diploma to evidence formal legal training for the purposes of practising in the courts, or to issue a fatwa or to teach law at mosques and other relevant places. The literature is silent on this issue which leaves modern researchers, including Makdisi, unable to discuss legal education and training during this period of Islamic history.

It was only during the fifth/eleventh century that one sees professionalisation and development of guilds of law: ${ }^{47}$ (a) the apprentice being the undergraduate law student (mubtadi or mutafaqqih) who normally spent four years of legal study under the direction of one master ${ }^{48}$ (b) the journeyman being the graduate (șa hib or faqih) who, if he wished, could go on to graduate studies that lasted an indefinite period of time ${ }^{49}$, and (c) the master being the master-jurisconsult ( $f a q \bar{i} h$ or $m u f i \overline{\text { }}$ ), accredited as such by the license to teach law and issue legal opinions (ijäzat al-tadris wa l-iftä')..$^{50}$ This legal education and training was conducted in a college of law which began in a mosque and was later developed to a hostel or khän for out-of-town students. These lodging places are the Islamic inns of court exclusively for law students. ${ }^{51}$

This brief account about legal education and the certificates to teach and issue a fatwa (ijäzat al-tadris wa-l-iftá') is unfortunately silent on the question of professional certificates to practise in courts either as judges or the shähidnotary (professional notary witness) or other auxiliaries of the office of the $q \bar{a}(\underline{c} \bar{i}$ and the court. As for the post of the shāhid-notary, Makdisi points out that the post was available only to the student who had successfully completed his legal studes ${ }^{52}$ which was presumbly done in four years. However, Makdisi

\footnotetext{
${ }^{47}$ Makdisi, G., «The Guilds of Law in Medieval Legal History: An Inquiry Into the Origins of Court», Cleveland and State Law Review, vol. 34, 1985-1986, 9.

${ }^{48}$ Ibid., Encyclopaedia of Islam [New Edition], vol. 5, 1124 (see Madrasa).

${ }^{49}$ Ibid.

${ }^{50}$ Ibid.

${ }^{51}$ Encyclopaedia of Islam [Madrasa], 1124.

${ }_{52}$ Makdisi. G., The Rise of Colleges: Institutions of Learning in Islam and the West, Edinburgh University Press, 1981, 201.
} 
has indicated that both the shāhid and $q \bar{a} \underline{̣} \bar{\imath}$ are of professor level and were accredited to teach law. ${ }^{53}$ This statement gives the impression that judges particularly in the fifth century of Hijra were academically sound and of professional level.

However, we are not in position to verify this statement as there is no reliable measure of the academic qualifications of the muftis, professors of law and, what more, of the judges. Makdisi has rightly pointed out that Islamic law is always individualistic; this may be seen in the function of the qāḍ the mudarris or professor of law, as well as in the madrasa, the college of law. Being individualistic, the $q \bar{a}$ ḍ $\bar{\imath}$ was alone responsible for his legal decisions; the mufti was alone responsible for his legal opinions, based on ijtihād, and individual personal activity of research into the sources of law. ${ }^{54}$ The most striking example is the issuance of licence to teach (ijäzat al-tadris) or in the Christian West, the licentia docendi which is granted to a doctorate holder who has defended his own thesis against opponents. The practice was longestablished in the Islamic world before it emerged in law university of Bologna, in the London Inns of Court, as well as in Paris, Oxford and even Salerno. However, the practice of conferment of degrees, unlike in the Christian West, was not institutionalised as the practice was always individualised..$^{55}$

On the other hand, in relation to qualifications and professional certificates for judgeship, one is perplexed to find out that the nomination and selection of judges were not exclusively based on academic qualifications or reputation. As the second half of the Abbasid goverment started to witness the establishment of schools of law by their respective founders and master architects, the post of judgeship should ideally have been taken by the most qualified academician. However, this was not the case. During that period, many leading jurists were available not only in Baghdad, but also in other provinces such as in Medina, Egypt and other localities. For example, while both al-Layth $\mathrm{b}$. Sa'd and Imām al-Shāfi' 'ì (d. 204/820) were in Egypt, Imām Mālik b. Anas (d. 178/795) was in Medina. Surprisingly enough, these great jurists were not even nominated for the post of judgeship in their respective provinces. However, there were a few leading jurists who were actually nominated for judgeship some of whom declined in spite of the insistence of the Caliph as in the case of Abū Hanīfa (d.

53 Ibid. Makdisi writes: «Like the qäḍ̆, the shähid frequently held the post of notary simultaneously with a professorship of law». The source of reference to this effect as cited by Makdisi is 'Abd al-Rahmmān b. Ismā'îl al-Maqdisī's Tarājim Rijäl al-Qarnayn al-Sādis wa al-Sābi ", ed. M. al-Kawthari, Cairo, 1947, 217.

54 Encyclopaedia of Islam [Madrasa], 1133.

5s Makdisi, Rise of Colleges, 270-276. 
150/767) while some others accepted the appointment as in the case of Abu Yūsuf, the most prominent student of Abū Hianïa.

What concerns us here is the position of Imām al-Shāfi 'ī in Egypt because his reputation as one of the leading jurists is beyond any doubt. Nevertheless, he was not nominated for the post. Instead, during his stay in Egypt, it was Lahī'a b. 'Īsā who was appointed as the Judge of Egypt (199-204/815-820). ${ }^{56}$ As a matter of fact, the Judge's biographical information is not as impressive as al-Shăfi 'i's. ${ }^{57}$ It is the perception of many researchers that among the reasons which restrained nominees from accepting the offer is that holding of post would render the administration of justice void of religious principles as judges were appointed by the Caliph vis-à-vis a secular authority. ${ }^{58}$ Presumably it is for this same reason that Imām al-Shāfi' 'i who was known to the authority as a person not interested in the post was not offered it, otherwise, al-Shāfi 'i would have accepted the post earlier still. This is supported by the report of al-Shīrāzi who states on the authority of his professor of law, Abū al-Tayyib al-Tabarī, that Abū 'Alī b. Khayrān (d. 320/932) chided the great Shāfi'ĩ scholar Ibn Surayj for accepting the post: "This matter was never indulged in by our companions; it was prevalent only among the followers of Abü Hanifa».59

This report, however, seems to contradict another report that Imām alShäfi' 1 himself had persuaded Ahmad b. Hanbal to accept the post of judgeship in Yemen in the time of Hārūn al-Rashīd but Ibn Hanbal refused. On the contrary, Ibn Hanbal firmly underscored that the reason why he affiliated himself with al-Shäfi' $1 \bar{i}$ was to acquire the knowledge and not to seek any post. Not only that, Ibn Hanbal is reported to have said that had alShāfi 'i repeated the same offer for the second time, he would have definitely left al-Shăfi 'ī's circle of knowledge for another professor of law for his legal education. ${ }^{60}$ As there is no reliable evidence of the reason for al-Shāfi 'i not being appointed a judge, the writer tends to consider this case as an exceptional case to al-Shāfi 'î because he may have preferred to be a professor of law rather than a judge. ${ }^{61}$

${ }^{56}$ Al-Kindī, Wulāt Mișr, 316-320.

57 Ibid.

${ }^{58}$ Makdisi, Rise of Colleges, 200

59 Ibn al-Jawzī, Abū al-Faraj 'Abd al-Rahmān, al-Muntazam fí Ta'rỉkh al-Mulūk wa al-Umam, vol. 7, 5-6, as cited by Makdisi, Rise of Colleges, 200.

${ }^{60} \mathrm{Ibn}$ al-Jawzī, Abū al-Faraj 'Abd al-Raḥmān, Manāqib al-Imām Aḥmad b. Hanbal, Cairo, $1349 \mathrm{H}, 280-281$.

${ }^{61}$ Al-Kindi reported one case where the nominee for the post declined to accept it arguing that the status of a qãậi would be inferior to that of jurists in the eyes of Allăh in the Hereafter (Wulāt Mișr, 314). 
No matter what the reason that led the Caliph or the local governor to appoint judges from non-leading jurists or non-professors of law, it is well established in the literature of judgeship that the judges were not always necessarily and sufficiently expert in law. ${ }^{62}$ As in the case of judges in Egypt, alKindī reported that Ghawth b. Sulaymān (135-140/753-758; 140-144/758-762; 167-168/784-785) was not a man of fiqh but he was known for his good understanding of judicial matters and its policies (kāna a lam al-nās bi ma'āni

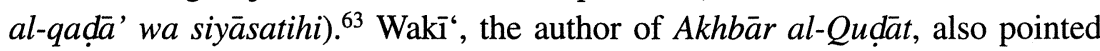
out some judges who were not professionally known as jurists such as 'Abd alRahmān b. Isḥāq ${ }^{64}$ and Muhammad b. Abī Rijāa ${ }^{6}{ }^{65}$ In another report, a candidate to the post of judgeship refused to accept the offer arguing that he was not wellversed in judicial matters nor in fiqh. Hārūn al-Rashīd, however, managed to persuade him by saying that he could resolve his problem in fiqh simply by consulting the experts of fiqh without affecting his career as a judge. ${ }^{66}$ As a matter of fact, there was a reported case whereby the presiding Judge, alMufaḍḍal b. Faḍāla, sought the confirmation of Imām Mālik b. Anas in Medina before pronouncing judgement in a case of blasphemy. ${ }^{67}$

Apart from formal and specific training for judiciary, we have some evidence to suggest that some of the judges were trained on the job as it were by the presiding judge. Put differently, the senior judge would, on many occasions, appoint his own deputy to assist him in judiciary tasks and to train him. In some cases, once the presiding judge retired or was dismissed or was not able to hear cases due to serious illness, his deputy would hear cases on behalf of the judge. The appointment of Ghawth b. Sulaymān as a judge in 135/753 succeeding the Judge Khayr b. Nu'aym is a good example. Ghawth was the scribe (kâtib) to Khayr in the court. As Khayr was suffering from judhām i.e. leprosy, he asked to be released from the office but this was rejected by Ibn Abī 'Awn, the local governor. He had no option but to authorise his scribe to deal with cases in his own house. ${ }^{68}$ In an-

\footnotetext{
${ }^{62}$ Madkisi points out that some $q \bar{a}$ dis did manage to be appointed as professors of law especially when the $q \bar{a} d \underline{c} i$ was a master-jurisconsult. See Makdisi, Rise of Colleges, 201 . The Muslim jurists have discussed the possibility of appointing the less preferred candidates over the best suited candidates for the post of judgeship and the prevailing view has been that it is lawful to do that with regard to judiciary in contrast to the appointment of the caliphs (wilàya 'àmma). See Ibn Abì al-Damm, Ibrāhīm b. 'Abd Allāh, Kitāb Ādāb al-Qaḍă', ed. Muḥammad 'Abd al-Qãdir 'Ațā, Beirut, 1987, 46.

${ }_{63}$ Al-Kindī, Wulāt Mișr, 269-270.

${ }^{64} \mathrm{Wakī}^{`}$, Akhbär al-Quḍăt, vol. 3, 283.

${ }^{65}$ Ibid., vol. 3, 289.

${ }^{66} \mathrm{Ibn}$ Qutayba, 'Uyün al-Akhbār, vol. 1, 17-18. However, the report explains that the appointee is well versed in mathematics (ibid.).

67 Al-Kindī, Wulāt Missr, 288.

68 Al-Kindī, Wulāt Miṣr, 268-269.
} 
other report, the Judge was asked to nominate the future judge and he nominated his scribe, Ghawth b. Sulaymān. ${ }^{69}$ This is further substantiated by the report that Ghawth, unlike Khayr b. Nu'aym, ${ }^{70}$ was not a noted scholar or faqih. Instead, he was acknowledged for his deep and sound knowledge of the judiciary and its policies and objectives. ${ }^{71}$ It seems that his close acquaintance with the Judge Khayr had exposed him indirectly but adequately to the skills of judicial works which are probably not to be found in any textbook.

Notwithstanding the above, there are many reports which acknowledge the high academic achievements of a few judges in Egypt. Included in this category are Abū Khuzayma Ibrāhīm b. Yazīd (144-154/758-771) who has recognised as a faqīh by Ibn Lahī'a, ${ }^{72}$ Ismā'îl b. al-Yasa' al-Kindī (164167/781-784) who was sent by Caliph al-Mahdĩ from Kufa, ${ }^{73}$ Abū Tāàir 'Abd al-Mālik b. Muhammad al-Ḥazmī (170-174/787-791) who was said to be very competent in the Māliki school of law, ${ }^{74}$ Isḥāq b. Furāt whose appointment was made on the merit of a strong and high recommendation by leading scholars of Egypt including Imām al-Shăfi 'ì who remarked that Isḥāq was well-versed in the disagreements of the jurists (käna yatakhayyar bi al$\left.a h k_{a} a \bar{m}\right),{ }^{75}$ Lahī'a b. 'İsā al-Ḥaḍramī (196-198/812-814) who was acknowledged both as faqīh and a muhḥadith (traditionalist), ${ }^{76}$ Ibrāhīm b. alJarrā (205-211/821-827) whose knowledge of figh is evident from reports of his judgment in which he deliberated and cited many juristic views on the dispute before arriving at his own verdict based on the facts of the case, ${ }^{77}$ alḤārith b. Miskīn (237-245/852-860), a jurist in the Mālikī school of law whose reputation superseded the more recognised jurist in the Māliki school of law i. e. Așbagh ${ }^{78}$ and Bakkār b. Qutayba (246-273/868-887) whose knowledge is not only testified by al-Muzanī, the author of Mukhtașar al-Muzanī but also

69 Wakī', Akhbār al-Qựāt, vol. 3, 232.

${ }^{70}$ Khayr was able to argue on the basis of the Qur'an that the mut'a payment in favour of the ex-wife is obligatory. For details, see al-Kindī, Wulät Misr, 263.

71 Ibid., 269.

72 Ibid., 275. This is further supported by the fact that Abü Khuzayma was nominated together with another two names for the post but his name was chosen by the local governor, Yazīd b. Hātim. See Ibn Hajar, Raf' al-Isr, vol. 1, 44.

73 Ibid., 280. He was the first judge who came from outside Egypt as well as the first Hanafi judge in Egypt (ibid.).

74 Ibid., 289.

75 Ibid., 296; Ibn Hajar, Raf' al-Ișr, vol. 1, 114. Al-Shāfi' ' 1 is also reported to have recommended Ishāq to some governors for the post of judgeship (Ibn Hajar, Raf' al-Isr, vol. 1, 1115).

76 Ibn Hajar, Raf' al-Issr, vol. 2, 288-289.

77 Ibid., vol. 1, 25; al-Kindī, Wulät Mișr, 326.

78 Ibn Hajar, Raf' al-Ișr, vol. 1, 168, 170, 171. 
was also able to produce his own writings to rebut the allegations of al-Shāfi 'i in Mukhtașar al-Muzanī against Abū Ḥanīfa. ${ }^{79}$

\section{DISMISSAL FROM JUDGESHIP}

The literature on this question normally mentions five reasons for the dismissal of a judge from his office. These reasons include injustices on the part of the judge, ${ }^{80}$ the physical condition of a judge that would hinder him from performing his duties diligently such as madness, blindness, deafness or an illness which is not curable as well as affecting his duties, ${ }^{81}$ inmoral practices of a judge (fisq) ${ }^{82}$ resignation ${ }^{83}$ and apostasy. ${ }^{84}$ However, during the period of the Abbasid's Egypt, it has been observed that some of the dismissals were brought about not by the judge's conduct but rather by the improper conduct and practices of the judge $a$ ' $w a \bar{n}$ or auxiliaries. The Abbasids, in order to assist the judge, had allowed the judge to appoint his own auxiliaries. There were court clerks, the kātib who kept the record of the cases, the muzakki who investigated and examined the character of ordinary witnesses and the mutarjim, the interpreter, who translated the witnesses' statements. ${ }^{85}$

The study has revealed that judges such as al-Mufaḍal b. Faḍala (174177/791-794) and 'Abd al-Rahmān b. 'Abd Allāh al-'Umarī (185-194/801810) were removed from the office simply because one of their assistants acted in the manner which was not proper and unjust. The former judge was dismissed because his witness officer, Fulayj b. Sulaymān, was bribed to include unreliable people in the list of witnesses who could testify. ${ }^{86}$ As for the latter judge, his auxiliaries were misusing and misappropriating public property kept in the bayt al-māl. The judge al-'Umari had to pay a high price for this as he was dismissed and imprisoned. ${ }^{87} \mathrm{He}$ was also accused personally to have

79 Ibid., 151, 154.

80 Ibn Farḥūn, Burhān al-Dīn Ibrāhīm b. 'Alī, Tabṣirat al-Hukkām fì Uṣūl al-Aqụiya waManāhij al-Aḥkām, Cairo, 1937, vol. 1, 79; Ibn Abī al-Damm, Ādāb al-Qāội, 73.

81 Ibn Farhūn, Tabṣirat al-Hukkām, vol. 1, 24.

82 Ibid., vol. 1, 78.

83 As the $q \bar{a} d \bar{l}$ is only an agent or representative appointed by the Caliph, the judge has an exclusive right to terminate the appointment by tendering his resignation. See Ibn Abĩ al-Damm, $\bar{A} d a ̄ b$ al-Qāọ̣i, 92; al-Ṭarābulusī, 'Alā' al-Dīn 'Alī b. Khalī, Mu'in al-Ḥukkām fì mã Yataradd bayn al-Khaṣmayn min al-Aḥkäm, Beirut, n. d., 33.

84 Al-Ṭaābulusī, $M u$ 'in al-Hukkäm, 33.

${ }^{85}$ Al-Mawsü'a al-Fiqhiyya, "Qāọā», Wizārat al-Awqāf wa-al-Shu'ūn al-Islāmiyya, State of Kuwait, 1995, vol. 33, 311-312.

86 Al-Kindī, Wulāt Miṣr, 290-291. 
misappropriated one hundred thousand dinars of public funds. ${ }^{88}$ Having said this, al-'Umari managed to keep the office for about nine years because the Caliph Hārūn al-Rashīd was reluctant to dismiss him as al-'Umarī was one of the descendants of 'Umar b. al-Khațāa ${ }^{89}$ The dismissal took place by the order of the governor of Egypt, Muhammad b. Hārūn, immediately after the death of Hārūn al-Rashīi. ${ }^{90}$

Related to the above discussion is the case of interference of a third party which affects the credibility of the office of a judge. This is where neither the judge nor his assistants were responsible for an action which rendered the performance of the judge questionable among the authorities and public. There is only one case pertaining to this aspect. It took place under the judgeship of Ibrāhim al-Jarrāh (205-211/821-827) who was acknowledged as a profound scholar as he always recorded the views of many leading jurists in his court decision..$^{91}$ His performance was well received until his son, Ishāa, came from Iraq, who then started interfering with court cases without the knowledge of the father. One interesting instance is where the son wrote a letter to his father's assistant to suspend the case which had been decided by this father. The letter was actually forged and this was found by the assistant after he investigated the matter. ${ }^{92}$

On the other hand, it is obvious that it was the judge who put himself to unnecessary trouble and the natural consequence was his dismissal from the office. The kind of actions varied from one judge to another. The dismissal of Judge Ismā'îl b. al-Yasa' al-Kindī (164-167/781-784), for example, was due to the fact that he was so committed and loyal to his school of law causing unnecessary hardship to the local people who were accustomed to a different school of law. As the Egyptians were Mālikis and approved the practice of habs, an opposite view will not be welcomed. However, the Judge, being a Hanafi scholar viewed that the practice should be deemed illegal. ${ }^{93}$ The worst part was his dispute with a leading Egyptian scholar, al-Layth b. Sa'd on the same legal point. As the Judge was so intransigent in his view, al-Layth wrote a letter to Caliph al-Mahdi complaining that the Judge seemed to harm and

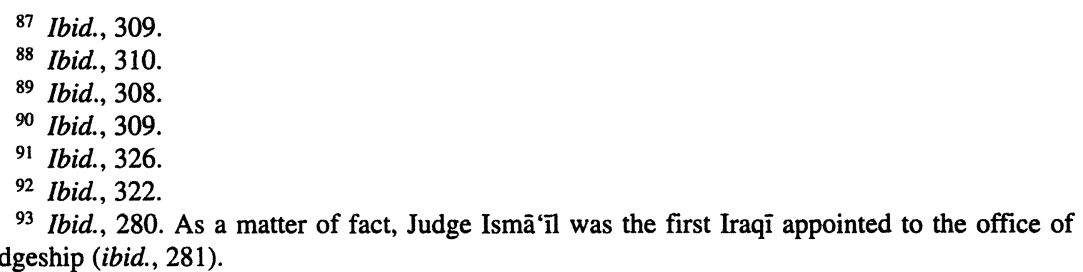


conspire against the Sunna of the Prophet which was prevalent in Egypt (innaka wallaytanā rajulan yakìdu sunnat Rasūl Allāh bayn aẓharinā) ${ }^{94}$ Based on the merits of the letter and perhaps the reputation of the writer himself, the Caliph in Iraq decided to dismiss Judge Ismā'îl in 167/784 although the Judge was renowned as a scholar and pious person. ${ }^{95}$

Similarly, Judge 'Īsā b. al-Munkadir (212-215/828-831) faced dismissal by his unwise action. He was appointed by the local governor after consulting a group of leading scholars in Egypt. ${ }^{96}$ Before appointment, he had been close to a group of people who were actively involved in amr bi al-ma'rüf wa nahy 'an al-munkar (i. e. Sūfis). When he assumed office, he was approached by this group to use his «power» to prevent wrong-doing by the newly appointed local governor, Abū Ishāq al-Rashīd. Upon listening to their allegations, he took immediate action (unfortunately without investigating the allegation!?). Although the Judge was advised by his assistants not to take any action he remained firm. He argued, it was necessary to uphold the law and rights of Allah. The group suggested to him to write a letter to Caliph al-Ma'mūn expressing his dissatisfaction with the new local governor and he did write to that effect. The Caliph was patient enough to call for his governor to defend himself against the allegations which the governor did. For this simple but unwise action, the judge was dismissed, put in prison in Egypt, before he was transferred to the central prison in Iraq where he died..$^{97}$ More interestingly, there was a judge who was dismissed due to his offensive attitude to the local people. Muhammad b. Masrūq al-Kindī (177-184/794-800) was removed from office as he was so arrogant and too strict in implementing his decisions in a manner which was unprecedented..$^{98}$

It is also vital to note that many dismissal cases were «politically inspired». In other words, the judges were dismissed not because of their poor performance in court. Instead, some of the judges were dismissed because they disapproved an intervention by the political authority in the court proceedings. An excellent example is the case of Judge Khayr $b$. Nu'aym who was unhappy when the local governor issued an order to release a soldier who was put into

94 Ibid., 281

95 Ibid., 280. There is another report that reveals a different reason leading to his dismissal which was his illness after eating poisonous food prepared by both the head of post office (i.e. Sirāj b. Khālid) and a newly appointed governor of Egypt (i.e. Ibrāhīm b. Șāliḥ). The reason was that the Judge Ismā'il refused to cooperate with them to take advantage from the goverment posts for their personal interests (ibid., 281-282).

96 Ibid., 327.

97 Ibid., 332.

98 Ibid., 293-295. 
prison by Judge Khayr because the former was not able to bring two male witnesses to support his false accusations of $z i n \bar{a}$ (qadhf). The Judge refused to resume his duties although the local governor had asked him to. Subsequently, the Judge was dismissed. ${ }^{99}$ Political dismissal was more obvious in the reign of Caliph al-Mu 'tașim when he removed his judge in Egypt, Hārūn b. 'Abd Allāh (217-226/832-841) because the judge did not comply with the Caliph's instructions to subject all the jurists and scholars in Egypt to the test (fitna) on the issue of the polemical question about the creation of al-Qur'ann. ${ }^{100}$ As a result, he was initially prevented from issuing any court decisions before being eventually dismissed from office to give way to Muhammad $b$. Abī al-Layth alKhwārizmī (226-237/841-852) to take the office of judgeship simply because the latter was more prepared to enforce the Caliph's desire and political/ideological doctrine in the fullest sense. ${ }^{101}$

\section{CONCLUSION}

In conclusion, we may note that most of the judges were knowledgeable in Islamic law even though they were not necessarily amongst the leading scholars except in the case of a few judges. These judges with high legal education were known to both the public and the appointing authority. This is obvious as some of the appointments were on the strength of nomination by scholars either in Egypt or in Baghdad. However, it now becomes obvious that there were no formal academic qualification certificates issued by the Central Goverment to the qualified candidates for the post of judgeship. The appointment was simply by letter of appointment ${ }^{102}$ and the same procedure would have probably applied to dismissals. We also note that most of the appointments came from the Caliph himself rather than the Chief Judge in the capital city. Even, in the case of appointment by the local governor, it seemed that the appointments were later endorsed by the respective Caliphs. It is very interesting to note that there

\footnotetext{
99 Ibid., 269.

100 Ibid., 338. Although Hārūn b. 'Abd Allāh had already rejected the witnesses who refused to accept the doctrine that al-Qur'ān is makhlüq, he had no courage to subject the scholars to this fitna (ibid., 337-338).

101 Ibid., 338-339.

102 Al-Māwardī says that a $q \bar{a}$ ḍ̣ may be appointed by means of oral order in case the proposed appointee is present, and by means of written order in case the appointee is not present before the appointing authority. The order should be clear and expressed in words that mean that the Imām or his deputy, as the case may be, have appointed such and such person at such and such place to administer the justice at the court of law (al-Ahkām al-Sulțaniyya, 66).
} 
were judges who were dismissed but later reappointed to the post, as in the case of Ghawth b. Sulaymān for the third time (167-168/784-785) after being dismissed in his second appointment (140-144/758-762). Likewise, Lahī'a b. 'Īsā al-Hadramī (196-198/812-814 and 199-204/815-820) was reappointed by the local governor who had himself dismissed Lahī'a in the first place. ${ }^{103}$ This shows that the judges were of high credibility, at least, in the eyes of the local governor(s) because the previous dismissal did not necessarily disqualify the dismissed judge from future appointment.

As for dismissals, many factors contributed. While some reasons are personal, other reasons are beyond the control of a judge as they normally involve political intervention. However, there was no case of dismissal due to serious moral flaw or lack of knowledge. As for personal shortcomings, the majority of the cases involved improper conduct of the judges' assistants which resulted in the judges' termination. Generally speaking, one contemporary scholar has observed that the rate of dismissal of the judges in the Abbasid period was relatively small compared to the Umayyad's. Of course, the reason was that the judges in the Abbasid period, unlike in the Umayyad period, were appointed by the central goverment and not by the local governors. ${ }^{104}$ Therefore, the power to dismiss the judges lay in the hand of the Caliphs or alternatively the Chief-Judge. Equally interesting is the principle of law that upon the death of the appointing authority, the $q \bar{a} \bar{d} \bar{\imath}$ will continue in his office and no fresh appointment by the succeeding ruler is required because the office of qāặ is a branch of wilāya 'āmma and therefore, the demise of the ruler does not make any difference to its validity. ${ }^{105}$

Out of many judges in Egypt in this period of time, it was only Judge Ghawth $\mathrm{b}$. Sulaymān who was offerred a post in the capital city because he was able to decide on one case involving the Caliph, Abū Ja'far al-Manșūr, and his wife, Umm Musā, in a manner agreeable to both the parties. However, Ghawth turned down the offer as he found it to be more convenient to be in Egypt. ${ }^{106}$ The profile of the judges also reveals that the judges were of different schools of law which tend to refute the prevailing view in the secondary sources that the judges in Egypt were of a homogeneous out look belonging to one school of law, that is Shāfi i 1 school of law. ${ }^{107}$

103 Al-Kindī, Wulāt Miṣr, 315, 316.

104 Al-Zuhaylī, Wahba, Ta'rikh al-Qadă' fi al-Islām, Beirut, 1995, 234.

105 Al-Mawsü'a al-Fiqhiyya, «Qāḍ̂a», vol. 13, 321.

106 Ibid., 283-284.

107 Muḥammad 'Azam, 'Abd al-'Azīz, al-Niz̄ām al-Qaḍāi fî al-Islām, al-Mu'assasa al'Arabiyya al-Hadītha li al-Tab' wa-al-Nashr, Cairo, n. s., vol. 1, 49; al-Humaydī, Sulaymān b. Muhammad, al-Qaḍa' wa Niz̄āmuhu fí al-Kitāb wa-al-Sunna, Markaz Buhūth al-Dirāsāt alIslāmiyyah, Mecca, 1984, 283. 
Equally true it is that the Chief-Judge was not directly or indirectly involved in the appointment and dismissal of judges in Egypt. This finding seems to contradict the prevailing view in most of the secondary sources that the Chief Judge was given the ultimate authority to appoint as well as dismiss judges in the local provinces. Perhaps the only exception, to the best of the writer's knowledge, relates to the dismissal of al-Hārith b. Miskin (237-245/852-860). $\mathrm{He}$ was dismissed by the Chief Judge in Baghdad, Ja'far b. 'Abd al-Wãhid. Even then, the dismissal was effected on the instructions of the Caliph alMutawakkil. ${ }^{108}$ The study also discloses that not all of the judges were Egyptian, a few of them came from Küfa and this is not surprising because Küfa, at that time, was the centre of legal education.

\begin{abstract}
This paper attempts to examine and analyse both the appointment and dismissal of Muslim judges from the historical perspective of academic qualification. The focus of this piece of research is the practice of the judiciary in Egypt during the Abbasid period (132-254/750-868). The main references are Wakī's Akhbär al-Quḍāt and al-Kindī's Kitäb Wulät Mișr. These books are highly original and relatively comprehensive and offer fairly detailed information on issues pertaining to both the appointment and dismissal of judges particularly in early Islamic history of Egypt. The profile of each and every judge is scrutinised to appreciate reasons leading to both their appointment and dismissal. The finding of the research might be useful to understanding judicial practices and their relation to the profession or qualification scheme which was followed at that point in time.
\end{abstract}

\title{
RESUMEN
}

Este artículo pretende analizar tanto el nombramiento como el cese de los cadíes desde el punto de vista de sus cualificaciones académicas. Se centra en la práctica del cadiazgo en Egipto durante el período 'abbāsí (132-254/750-868). Las fuentes principales son los Ajbār al-quḍāt de Wakī' y el Kitāb wulāt Miṣr de al-Kindī. Ambas obras contienen material de una gran originalidad y son bastante completas, ofreciendo detallada información sobre temas relativos tanto al nombramiento como al cese de los jueces

108 Ibn Ḥajar, Raf' al-Iṣr, vol. 1, 189. 
durante los primeros siglos de la historia islámica de Egipto. Se estudia la biografía de cada juez para averiguar cuáles fueron las razones que determinaron su nombramiento y su cese. Los resultados obtenidos son de interés para comprender las prácticas judiciales y su relación con las aptitudes profesionales que se consideraban necesarias en aquella época. 